\title{
Martin Geck
}

\section{Sinfonia f-Moll}

1 944, Kinderlandverschickung, Bregenzer Wald, Schwarzenberg. In der Wohnstube des Onkels steht ein Volksempfänger. Manchmal droht die Stimme des Führers. Und eine Frauenstimme schmeichelt heißkalt: "Heimat, deine Sterne".

Sie geht mir nach, die Stimme, bei der einsamen Pirsch durch die Wiesen:Verführton für Pfarrerskinder. Macht einen kleinen Rausch und die Beine schwer - zu schwer für einen Achtjährigen, der heim will zu den Bombennächten und zu seiner Mutter.

Sonntags ist die Kirche weit weg und der Pfarrer katholisch. Am Radio hören wir das ,Schatzkästleinc: knorrige Geschichten mit Feiertagsmusik. Ist das der Friede, um den wir beten? Die Zeitung schreibt mit großen Buchstaben: »V2, die neue Wunderwaffe«. Tante schaut nicht auf bei meiner Frage.

Der alte Mann im Radio erzählt von Vater, Sohn und Esel - wer darf reiten? Danach Silberklänge - bis heute in meinem Ohr: Seufzer steigen in den Himmel, flattern sich frei wie Vögel. Im Bauch wächst ein Gefühl, kein Heimweh, nur alles Leid der Welt. Und Trost: Mit dem dritten Seufzer bestäubt er mich von oben. Tonleiter und Kadenz soll ich das später nennen.

Das ist nicht die Musik der schönen Sängerin, deren roten Mund ich mir im Zigarettenbildchen näherhole. Jeder Ton baut an einer Welt, tief in mir drin. Nicht parfümsüß, aber ein windschlanker Baum, an dem schwere Früchte der Trauer schaukeln.

Mutter ist wohl tot. Früher hat sie gesungen. 